\title{
Bioderived Energy Sources for Protected Horticulture
}

\author{
sponsored by the \\ ASHS Growth Chambers and Controlled Environments Working Group \\ Cosponsored by the Crop Physiology, Mineral Nutrition, Water Utilization and Management; \\ International Topics of Concern to Horticulturists, Waste Utilization in Horticulture Working Groups \\ Organized by \\ Cary A. Mitchell, Purdue University, West Lafayette, Ind. \\ Corinne J. Rutzke, Cornell University, Ithaca, N.Y. \\ Donald T. Krizek, U.S. Department of Agriculture, Beltsville, Md. \\ Comoderators Cary Mitchell and Corinne Rutzke
}

held at the

ASHS Centennial Conference

Providence, Rhode Island

3 October 2003 